\title{
ALUR PEMERIKSAAN SENGKETA TATA USAHA NEGARA MELALUI GUGATAN KE PENGADILAN TATA USAHA NEGARA
}

\author{
Defil \\ defilpiliang@gmail.com \\ 2010003600437 \\ Universitas Ekasaksi
}

\section{A. PENDAHULUAN}

Makalah ini saya tulis adalah untuk melaksanakan tugas yang diberikan oleh dosen pengampu mata kuliah Hukum Acara Peradilan Tata Usaha Negara pada masa Ujian Akhir Semester III di Universitas Ekasakti (UNES). Adapun makalah ini membahas tentang Alur Pemeriksaan Sengketa Tata Usaha Negara di Pengadilan Tata Usaha Negara (PTUN). Sebagaimana kita ketahui, Peradilan TUN merupakan salah satu dari beberapa peradilan yang ada di Negara Republik Indonesia. Peradilan TUN sama halnya dengan peradilan umum, peradilan agama yakni sama-sama berada di bawah Mahkamah Agung (MA) Republik Indonesia.

Hanya saja perkara yang diadili dalam di peradilan TUN berbeda dengan peradilan lainnya. Jika peradilan Agama menyelesaikan perkara yang berkaitan dengan perkawinan atau pernikahan, maka di peradilan TUN membahas tentang sengketa administrasi atau keputusan yang dikeluarkan oleh pejabat pemerintahan dengan perorangan atau antara pemerintahan dengan badan hukum.

Adapun tujuan kita membahas tentang alur pemeriksaan perkara di Peradilan TUN adalah untuk mengetahui tahapan-tahapan yang harus dilewati oleh para pihak dalam bersengketa di peradilan TUN. Selain itu kita juga mengetahui tujuan dari masing-masing tahapan pemeriksaan perkara di peradilan TUN juga tergambar. Di mana masing-masing alur atau tahapan yang dijelaskan dalam makalah ini saling berkaitan. Intinya, bagaimana para pihak, terutama pihak penggugat memperoleh keseimbangan informasi sehingga tidak mengalami kesulitan dalam mengajukan gugatan guna memperoleh keadilan yang memiliki kekuatan hukum tetap. 


\section{B. PEMBAHASAN}

Mekanisme pemeriksaan perkara di Peradilan Tata Usaha Negara (TUN) ada dua tahap. Pertama ada tahap persiapan dan yang kedua adalah tahap persidangan. Tapi bukan tidak mungkin pada tahap persiapan perkara tidak lanjut pada persidangan karena dalam tahap persiapan ada agenda yang namanya mediasi atau negosisi antara tergugat dan dan penggugat. Pada agenda mediasi ada dua kemungkinan kesimpulan yang dihasilkan, pertama kesepakatan damai antara kedua belah pihak sehingga pemeriksaan perkara tidak dilanjutkan ke tahap persidangan, dan yang kedua kesimpulannya adalah lanjut kepada persidangan karena tidak ditemukan kesepakatan damai antara kedua belha pihak.

Dua tahap pemeriksaan perkara di Peradilan TUN saling berkaitan atau tidak bisa dipisahkan. Kedua tahap itu saling berhubungan, baik itu nantinya perkara akan dilanjutkan ke persidangan mau pun tidak dilanjutkan ke persidangan. Dengan kata lain pemeriksaan persiapan harus dilewati oleh kedua belah pihak, baik itu pihak penggugat, mau pun pihak tergugat.

Saya akan uraikan dua tahapan mekanisme pemeriksaan perkara di Peradilan TUN tersebut, yakni:

\section{a. Tahap Pemeriksaan Persiapan}

Pemeriksaan Persiapan diatur dalam pasal 63 Undang-undang Nomor 5 Tahun 1986 yang menyatakan sebelum pemeriksaan pokok sengketa dimulai, hakim wajib mengadakan pemeriksaan persiapan untuk melengkapi gugatan yang kurang jelas.

Dalam pemeriksaan persiapan sebagaimana dimaksud tersebut, hakim wajib memberi nasihat kepada penggugat untuk memperbaiki gugatan dan melengkapinya dengan data yang diperlukan dalam jangka waktu 30 hari; dapat meminta penjelasan kepada Badan atau Pejabat Tata 
Usaha Negara yang bersangkutan; apabila dalam jangka waktu 30 hari penggugat belum menyempurnakan gugatan, maka Hakim menyatakan dengan putusan bahwa gugatan tidak dapat diterima; Terhadap putusannya tidak dapat digunakan upaya hukum, tetapi dapat diajukan gugatan baru.

Maksud disediakannya acara Pemeriksaan Persiapan adalah guna mengimbangi dan mengatasi kesulitan Penggugat memperoleh informasi atau data yang berada dalam kekuasaan Badan/Pejabat Tata Usaha Negara. Hal ini diperlukan mengingat kedudukan antara Penggugat dengan Badan/Pejabat Tata Usaha Negara berada pada posisi yang tidak seimbang. Dengan disediakannya Acara Pemeriksaan persiapan diharapkan posisi tersebut akan seimbang, yakni dengan cara memberikan kesempatan kepada hakim untuk meminta penjelasan kepada Badan/Pejabat Tata Usaha Negara yang digugat, bahkan Pejabat Tata Usaha Negara lainnya yang dipandang perlu ataupun mendengar keterangan siapa saja yang dianggap perlu oleh Hakim, juga mengumpulkan surat-surat yang dianggap perlu oleh hakim.

Segi positif adanya Acara Pemeriksaan Persiapan ini akan menimbulkan keyakinan awal bagi penggugat, bahwa setidak-tidaknya dari segi kewenangan absolut dan kewenangan relative serta syarat-syarat gugatan diyakini telah terpenuhi, sehingga gugatan tidak perlu diragukan dan dikhawatirkan kemungkinan dieksepsi oleh tergugat.

Meskipun demikian Majelis Hakim masih diberikan kewenangan untuk menyatakan gugatan tidak dapat diterima (niet onvankelijk verklaard) baik seluruhnya maupun sebagian, kendati gugatan telah lolos dari dismissal proses.

Penerapan pemeriksaan persiapan dalam peradilan tata usaha negara sebelum dilakukan pemeriksaan persiapan, surat gugatan yang masuk akan dilakukan penelitian administratif oleh 
panitera, wakil panitera atau panitera muda pengganti untuk mengetahui dipenuhinya syarat-syarat dari surat gugatan tersebut yaitu dilihat dari segi formalnya saja.

Kepada Hakim diberi kemungkinan untuk mengadakan pemeriksaan persiapan sebelum memeriksa pokok sengketa. Wewenang hakim ini untuk mengimbangi dan mengatasi kesulitan seseorang sebagai Penggugat dalam mendapatkan informasi atau data yang diperlukan dari Badan/Pejabat Tata Usaha Negara, mengingat Penggugat dan Badan/Pejabat Tata Usaha Negara kedudukannya tidak sama.

Dalam melakukan pemeriksaan setempat tidak perlu dilaksanakan oleh majelis hakim yang lengkap, cukup oleh seorang hakim anggota yang khusus ditugaskan untuk melakukan pemeriksaan setempat yang dituangkan dalam bentuk penetapan.

\section{b. Tahapan -Tahapan Pemeriksaan Perkara di Persidangan}

Pertama adalah pembacaan gugatan, sebagaimana diatur Pasal 74 Ayat 1 Undang Undang Nomor 5 Tahun 1986. Pada tahapan persidangan, pemeriksaan perkara dimulai dengan membacakan isi gugatan dan surat yang memuat jawabannya oleh hakim ketua sidang, dan jika tidak ada surat jawaban, pihak tergugat diberi kesempatan untuk mengajukan jawabannya.

Kemudian, ada tahapan pembacaan Replik sebagaimana diatur dalam Pasal 75 Ayat 1 Undang - Undang Nomor 5 Tahun 1986. Penggugat dapat mengubah alasan yang mendasari gugatan hanya sampai dengan replik, asal disertai alasan yang cukup serta tidak merugikan kepentingan tergugat, dan hal tersebut harus disaksikan oleh hakim.

Selanjutnya ada tahapan pembacaan duplik sebagaimana diatur dalam Pasal 75 Ayat 2 Undang - Undang Nomor 5 Tahun 1986. Tergugat dapat mengubah alasan yang mendasari 
jawabannya hanya sampai dengan duplik, asal disertai alasan yang cukup serta tidak merugikan kepentingan penggugat dan hal tersebut harus dipertimbangkan dengan seksama oleh hakim.

Kemudia masuk ke tahap pembuktian sebagaimana diatur dalam Pasal 100 Undang Undang Nomor 5 Tahun 1986. Yang dapat dijadikan alat bukti dalam persidangan adalah surat atau tulisan; keterangan ahli; keterangan saksi; pengakuan para pihak; pengetahuan hakim.

Selanjutnya adalah tahap kesimpulan sebagaimana diatur dalam Pasal 97 Ayat 1 Undang - Undang Nomor 5 Tahun 1986. Dalam hal pemeriksaan sengketa sudah diselesaikan, kedua belah pihak diberi kesempatan untuk mengemukakan pendapat yang terakhir berupa kesimpulan masingmasing pihak.

Terakhir adalah tahapan putusan sebagaimana diatur dalam Pasal 108 Undang - Undang Nomor 5 Tahun 1986. Putusan pengadilan harus diucapkan dalam sidang terbuka untuk umum; apabila salah satu pihak atau kedua belah pihak tidak hadir pada waktu putusan pengadilan diucapkan, atas perintah hakim ketua sidang salinan putusan itu disampaikan dengan surat tercatat kepada yang bersangkutan; Tidak dipenuhinya Ketentuan Sebagaimana dimaksud dalam ayat (1) berakibat putusan pengadilan tidak sah dan tidak mempunyai kekuatan hukum.

Adapun materi yang termuat dalam Putusan sebagaimana diatur dalam Pasal 109 Undang - Undang Nomor 5 Tahun 1986 yakni, kepala putusan yang berbunyi : " DEMI KEADILAN BERDASARKAN KETUHANAN YANG MAHA ESA" ; Nama, Jabatan, Kewarganegaraan, Tempat Kediaman, atau Tempat Kedudukan Para Pihak Yang Bersengketa ; Ringkasan gugatan dan jawaban tergugat yang jelas; Pertimbangan dan penilaian setiap bukti yang diajukan dan hal yang terjadi dalam persidangan selama sengketa itu diperiksa ; 
Kemudian harus dimuat alasan hukum yang menjadi dasar putusan ; Amar putusan tentang sengketa dan biaya perkara ; Hari, tanggal putusan, nama hakim yang memutus, nama panitera, serta keterangan tentang hadir atau tidak hadirnya para pihak.

Bunyi amar putusan sebagaimana diatur dalam Pasal 97 ayat 7 Undang - Undang Nomor 5 Tahun 1986 yakni, Gugatan Ditolak; Gugatan Dikabulkan; Gugatan Tidak Diterima; Gugatan Gugur. 


\section{PENUTUP}

Dari uraian yang sudah disampaikan dalam pembahasan diatas maka dapat disimpulkan sebagai berikut :

1. Pemeriksaan Persiapan merupakan prosedur pendahuluan dalam Peradilan Tata Usaha Negara yang memberikan kewenangan kepada Majelis Hakim yang telah ditetapkan oleh Ketua Pengadilan, agar wajib mengadakan pemeriksaan persiapan untuk melengkapi gugatan yang kurang jelas atau untuk mematangkan perkara sebelum pemeriksaan pokok sengketa di muka umum dimulai, yang ketentuannya dapat dilihat dalam Pasal 63 Undang-undang Nomor 5 Tahun 1986.

2. Pemeriksaan Persiapan ini dapat pula dilakukan oleh Hakim Anggota yang ditunjuk oleh Ketua Majelis sesuai dengan kebijaksanaan yang ditetapkan oleh Ketua Majelis.

3. Pada tahapan persidangan kedua belah pihak bisa mengubah isi gugatan atau jawaban pada agenda sidang replik dan duplik sepanjang tidak merugikan antara dua belah pihak

4. Jika para pihak tidak hadir dalam pembacaan putusan, peradilan TUN wajib menyampaikan salinan putusan kepada para pihak dalam bentuk copy.

\section{DAFTAR PUSTAKA}


Darmini Roza dan Laurensius Arliman S, Peran Pemerintah Daerah Di Dalam Melindungi Hak Anak Di Indonesia, Masalah-Masalah Hukum, Volume 47, Nomor 1, 2018. https://doi.org/10.14710/mmh.47.1.2018.10-21

Laurensius Arliman S, Peranan Metodologi Penelitian Hukum di Dalam Perkembangan Ilmu Hukum di Indonesia, Soumatera Law Review, Volume 1, Nomor 1, 201. http://doi.org/10.22216/soumlaw.v1i1.3346.

Laurensius Arliman S, Peran Badan Permusyawaratan Desa di Dalam Pembangunan Desa dan Pengawasan Keuangan Desa, Padjadjaran Journal of Law, Volume 4, Nomor 3, 2017. https://doi.org/10.15408/jch.v4i2.3433.

Laurensius Arliman S, Penanaman Modal Asing Di Sumatera Barat Berdasarkan Undang- Undang Nomor 25 Tahun 2007 Tentang Penanaman Modal, Supremasi Hukum, Volume 1, Nomor 1, 2018. http://dx.doi.org/10.36441/hukum.v1i01.102 .

Laurensius Arliman S, Memperkuat Kearifan Lokal Untuk Menangkal Intoleransi Umat Beragama Di Indonesia, Ensiklopedia of Journal, Volume 1, Nomor 1, 2018, https://doi.org/10.33559/eoj.v1i1.18.

Laurensius Arliman S, Perkawinan Antar Negara Di Indonesia Berdasarkan Hukum Perdata Internasional, Kertha Patrika, Volume 39, Nomor 3, 2017, https://doi.org/10.24843/KP.2017.v39.i03.p03.

Laurensius Arliman S, Partisipasi Masyarakat Di Dalam Pengelolaan Uang Desa Pasca UndangUndang Nomor 6 Tahun 2014 Tentang Desa, Jurnal Arena Hukum, Volume 12, Nomor 2, 2019, https://doi.org/10.21776/ub.arenahukum.2019.01202.5.

Laurensius Arliman S, Mewujudkan Penegakan Hukum Yang Baik Di Negara Hukum Indonesia, Dialogica Jurnalica, Volume 11, Nomor 1, 2019, https://doi.org/10.28932/di.v11i1.1831.

Laurensius Arliman S, Mediasi Melalui Pendekatan Mufakat Sebagai Lembaga Alternatif Penyelesaian Sengketa Untuk Mendukung Pembangunan Ekonomi Nasional, UIR Law Review, Volume 2, Nomor 2, 2018, https://doi.org/10.25299/uirlrev.2018.vol2(02).1587

Laurensius Arliman S, Peranan Filsafat Hukum Dalam Perlindungan Hak Anak Yang Berkelanjutan Sebagai Bagian Dari Hak Asasi Manusia, Doctrinal, Volume 1, Nomor 2, 2016.

Laurensius Arliman S, Ni Putu Eka Dewi, Protection of Children and Women's Rights in Indonesia through International Regulation Ratification, Journal of Innovation, Creativity and Change Volume 15, Nomor 6, 2021.

Laurensius Arliman S, Gagalnya Perlindungan Anak Sebagai Salah Satu Bagian Dari Hak Asasi Manusia Oleh Orang Tua Ditinjau Dari Mazhab Utilitarianisme, Jurnal Yuridis, Volume 3, Nomor 2, 2016, http://dx.doi.org/10.35586/.v3i2.180.

Laurensius Arliman S, Tantangan Pendidikan Kewarganegaraan Pada Revolusi 4.0, Jurnal Ensiklopedia Sosial Review, Volume 2, Nomor 3, 2020.. 